\title{
Prevalence, Detection Of Marker And Virulence Genes Of Methicillin- Resistant Staphylococcus aureus (MRSA) Isolated Form Milk And Dairy Products And Their Antimicrobial Susceptibility
}

\author{
Maha AM Al-Ashmawy ${ }^{1}$ and Khalid Ibrahim Sallam ${ }^{1}$
'Department of Food Hygiene and Control, Faculty of Veterinary Medicine, Mansoura University
}

\begin{abstract}
The present work was undertaken to study the prevalence, genetic profile and antimicrobial susceptibility of methicillin-resistant Staphylococcus aureus (MRSA) in raw milk and dairy products in Mansoura City, Egypt. MRSA was detected in 53\% (106/200) among all milk and dairy product samples with prevalence rates of $75 \%(30 / 40), 65 \%(26 / 40), 40 \%(16 / 40), 50 \%$ $(20 / 40)$, and $35 \%(14 / 40)$ in raw milk, Damietta cheese, Kareish cheese, ice cream, and yoghurt samples, respectively. The mean $S$. aureus counts were $3.49,3.71,2.93,3.40$ and $3.23 \log _{10} \mathrm{cfu} / \mathrm{g}$ in the tested raw milk, Damietta cheese, Kareish cheese, ice cream and yoghurt, respectively, with an overall count of $3.41 \log _{10} \mathrm{cfu} / \mathrm{g}$. Unexpectedly, all of the $S$. aureus isolates $(n=414)$ detected mere genetically verified as MRSA strains. PCR analyses verified the existence of nuc, cou, and The antimicrobial the 414 isolates. All of the 414 MRSA isolates were also positive for hla gene. indicated that the least effective drugs for the 414 MRSA strains against 13 tested antimicrobials with bacterial resistance percentages of $87.9 \%, 75 \%$, cloxacillin, tetracycline, and amoxicillin most effective antimicrobials against trimethoprim, ciprofloxacin, netilmicin, and isolates were vancomycin, sulphmethazole/ percentages of $76.3 \%, 75.4570 .1 \%, 69.1 \%$, gnd 63.9 , which revealed bacterial sensitivity tested, $348(84.1 \%)$ were multidrug resista , and $63.3 \%$, respectively. Of the 414 MRSA strains of MRSA isolated from milk and dairy products in study presents the first genetic characterization
\end{abstract}

\section{INTRODUCTION}

Staphylococcus aureus has become one of the most important pathogens in microbiological safety and quality of food (I). $S$. aureus is ubiquitous in nature. It is highly vulnerable to destruction by heat treatment and nearly all sanitizing agents. Thus, the presence of this bacterium or its enterotoxins in processed foods or in food processing equipment is generally an indication of poor sanitation (2). S. aureus counts should reach 6 $\log _{10} \mathrm{cfu} / \mathrm{g}$ of food to produce sufficient amounts of enterotoxins to cause illness (3).

Foods of animal origin, specially milk and dairy products, are associated with foodborne discases $(4,5)$. Milk is a good substrate for $S$. aureus growth, and the dairy products are a weil-known source of intoxication. The enterotoxigenic $S$. aureus have been reported to Cause contamination of raw milk $(6,7)$, cheeses $(8,9)$; ice cream (10); and yoghurt (11).

S. aureus may be contaminating milk and dairy products from the udder of dairy animal, from human beings, and from inadequately cleaned equipment. It is also a major causative pathogen for clinical or subclinical mastitis of dairy domestic ruminants (12).

The enumeration of Staphylococci was routinely conducted on dairy products as a good indicator of quality of sanitation during its 
production and distribution and to establish the occurrence of post-processing contamination (13).

Enterotoxigenic $S$. aureus is the major bacterial pathogen that develops multidrug resistance to antibiotics (14). Methicillinresistant $S$. aureus (MRSA) is often present in various kinds of food and causes foodborne intoxication (15). Kluytmans et al. (16) reported the first foodborne outbreak of MRSA that caused the death of 5 out of 21 patients. The $m e c A$ gene considered as a useful molecular marker of putative methicillin resistance in coagulase-negative staphylococci (CoNS) and S. aureus (17).

Kareish cheese (acid curd skim milk cheese) is a kind of homemade soft cheese manufactured in Egyptian villages and can be considered the main protein supplement consumed by most Egyptian farmers, while Damietta cheese is a famous soft, white pickled cheese industrially processed and distributed in Egypt under different market names. Unfortunately, there is uncontrolled use of antimicrobial agents for treatment in Egypt which make the screening for antibacterial agent of $S$. aureus organisms is very important. The present study was planned to throw light on the Prevalence, genetic profile and antimicrobial susceptibility of MRSA in raw milk, Damietta cheese, Kareish cheese, ice cream, and yoghurt marketed in Mansoura City, Egypt.

\section{MATERIAL AND METHODS}

Milk and dairy products samples

A total of 200 samples (40 each of raw milk, Damietta cheese, Kareish cheese, ice cream and yoghurt) were collected from retail outlets, different shops and supermarkets in Mansoura City, Egypt. All samples were transported in a refrigerated box $\left(4\right.$ to $\left.8{ }^{\circ} \mathrm{C}\right)$ to
Food Hygiene and Control Department Laboratory, Mansoura University, Egypt, where the conventional bacteriological analysis was done immediately.

\section{Enumeration and Isolation of $S$. aureus}

The count of $S$. aureus was determined according to (13) by using surface plate technique onto Baird Parker agar (BP) with Egg Yolk Tellurite Emulsion (Baird Parker, Oxoid, CM0257; Egg Yolk Tellurite Emulsion, Oxoid, SR0054) followed by incubation at $37{ }^{\circ} \mathrm{C}$ for 48 h. Suspected colonies (1-12) were selected and picked up onto a slope agar, purified and identified biochemically according to Bennett and Lancette (2).

Molecular characterization of MRSA

Molecular identification and characterization of the isolated S. aureus strains was carried out in Bioproduction Research Institute, National Institute of Advanced Industrial Science and Technology (AIST), Hokkaido, Japan. Genomic DNA of S. aureus isolates was prepared according to the method described by Sallam et al. (18) with the use of Maxwell 16 cell DNA purification kit (Promega Corporation, Madison, WI, USA). Genomic DNA from E. coli K $12 \mathrm{DH} 5 \alpha$ strain was similarly prepared and used as a negative control template for PCR analyses.

PCR was conducted for the presence of the marker genes nuc, coa, and mecA, as well as hla virulence gene. Primer sets used for PCR amplification of the target genes are listed in Table (1). The oligonucleotide primers were synthesized by Hokkaido System Science Co. Ltd. (Hokkaido, Sapporo, Japan).

GeneAmp PCR system 2700 thermal cycler (Applied Biosystems, Foster City, CA, USA) was used for detection of the various target genes. PCR was carried out in a $20-\mu 1$ reaction mixture containing $1.6 \mu \mathrm{l}$ S. aureus genomic DNA template, $1 \mu \mathrm{l}(6 \mathrm{pmol})$ for each of forward and reverse primers, $4 \mu \mathrm{l}$ dNTPs (2 $\mathrm{mM}), 0.4 \mu \mathrm{l}$ KOD FX Neo Polymerase enzyme $(1.0 \mathrm{U} / \mu \mathrm{l}), 10 \mu \mathrm{l}$ of $2 \times \mathrm{PCR}$ Buffer for KOD FX Neo (Toyobo Co., Ltd., Japan) and $2 \mu \mathrm{l}$ PCR 
grade water. After an initial denaturation at 94 ${ }^{\circ} \mathrm{C}$ for 2 min. 35 cycles PCR amplification cycles consisting of denaturation at $98{ }^{\circ} \mathrm{C}$ for $10 \mathrm{~s}$, annealing at $58{ }^{\circ} \mathrm{C}$ for $30 \mathrm{~s}$, and extension at $68{ }^{\circ} \mathrm{C}$ for $1 \mathrm{~min} / \mathrm{kbp}$, were performed followed by a final extension at $68^{\circ} \mathrm{C}$ for 7 min. Amplified genes of each PCR reaction mixture were separated by subjecting $3 \mu \mathrm{ul}$ aliquots to agarose $(1.2 \%)$ gel electrophoresis for $30 \mathrm{~min}$ at $100 \mathrm{~V}$ followed by a 20 -min staining in ethidium bromide solution. The separated PCR products were then visualized under UV light and photographed.

Table 1.Primer sets for PCR amplification of molecular identification of Staphylococcus
aureus

\begin{tabular}{clcc}
\hline Gene & \multicolumn{1}{c}{ Oligonucleotide primer sequences } & $\begin{array}{c}\text { Amplified } \\
\text { DNA size }\end{array}$ & References \\
\hline nuc & F: 5'-GTGCTGGCATATGTATGGCAATTG-3' & $660 \mathrm{bp}$ & $(18)$ \\
& R: 5'-CTGAATCAGCGTTGTCTTCGCTCCAA-3' & & \\
coa & F: 5'-TAGGCGCATTAGCAGTTGCATC-3' & $1000 \mathrm{bp}$ & $(18)$ \\
& R: 5'-CCAGCCGTAGTTTTAACCTCTTG-3' & & \\
mecA & F:5'-GATTGGGATCATAGCGTCA-3' & $1200 \mathrm{bp}$ & $(18)$ \\
& R:5'-CAGTATTTCACCTTGTCCG-3' & & \\
hla & F: 5'-CCGGTACTACAGATATTGGAAGC-3' & $744 \mathrm{bp}$ & $(18)$ \\
& R: 5'-GGTAATCATCACGAACTCGTTCG-3' & & \\
\hline
\end{tabular}

For confirmation of the amplified genes, DNA sequencing was completed using the BigDye Terminator v3.1 Cycle Sequencing Kit (Applied BioSystems) following the manufacturer's instructions on an ABI Prism 3100 automated sequencer (Applied Biosystems). Primers used for PCR for sequencing were the same used for DNA amplification. Nucleotide sequence data were then analyzed by the GENETYXMAC software, version 12 (GENETYX Corp., Tokyo, Japan).

Antimicrobial susceptibility testing

The Kirby-Bauer test for antimicrobial susceptibility, which is called the disc diffusion test, was applied according to Jorgensen and Turnidge (5). S. aureus strains were swabbed onto Muller-Hinton medium (Oxoid) and the antimicrobial discs (Oxoid) were placed on the top of the medium. The plates were then incubated at $35 \mathrm{C}$ for $24 \mathrm{~h}$. The presence or absence of an inhibitory area around the disc identifies the bacterial sensitivity to the drug. The zone sizes were looked up on a standardized chart to give a result of sensitive, resistant or intermediate.

\section{RESULTS AND DISCUSSION}

$\begin{aligned} & \text { Prevalence of MRSA in milk and dairy } \\ & \text { products }\end{aligned}$
a

In the present study, S. aureus (MRSA) was detected in 53\% (106/200) among all milk and dairy product samples tested with prevalence rates of $75 \%(30 / 40), 65 \%(26 / 40)$, $40 \%(16 / 40), 50 \%(20 / 40)$, and $35 \%(14 / 40)$ in raw milk, Damietta cheese, Kareish cheese, ice cream, and yoghurt samples, respectively (Fig. 1). Unexpectedly, all of the $S$. aureus isolates detected were genetically verified as MRSA strains. 


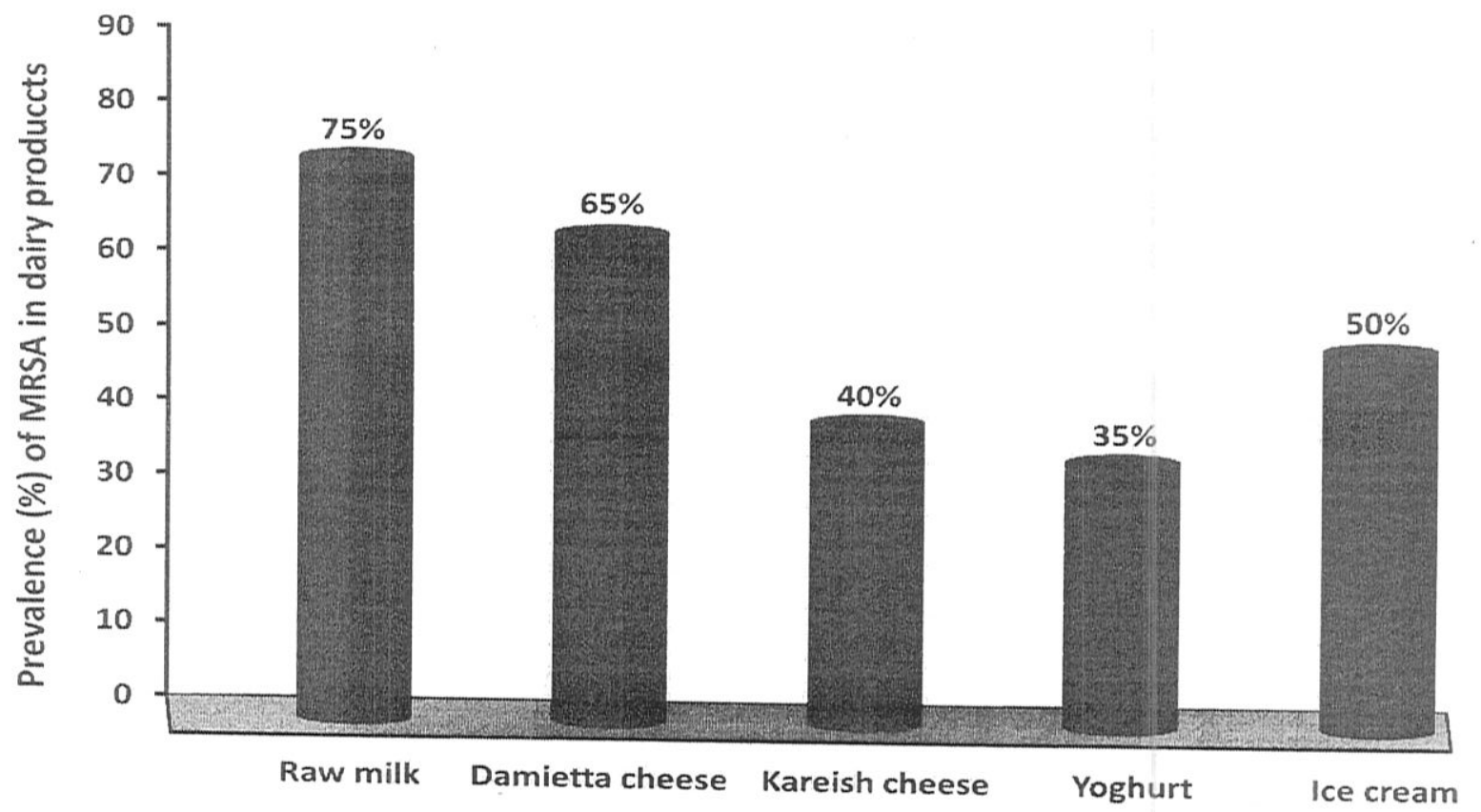

Fig. 1. Incidence of contamination of milk and dairy product samples with MRSA

Several studies were conducted in different countries to screen milk and dairy products for the presence of MRSA. A study in USA has identified MRSA in $21.8 \%(29 / 133)$ of bovine milk samples (19). Very low contamination rates for MRSA in milk and dairy products were recorded, however in different countries. Gücükoğlu et al. (10) revealed that 2.8\% (1/35) of ice cream samples tested in Turkey were positive for MRSA, while Normanno et al. (20) in Italy indicated that $3.75 \%(6 / 160)$ of dairy products were positive for MRSA. In Korea, Lee (21) revealed the occurrence of MRSA in $1.34 \%$ (12/894) of bovine milk samples. Another study in Iran revealed that 4\% (2/50) of both pasteurized milk and traditional soft cheese samples were positive for MRSA while it could not be detected in raw milk (22). In Turkey, $7.5 \%$ (3/40) of tested isolated $S$. aureus from Urfa cheese samples were MRSA (23). MRSA was not detected among any of the $S$. aureus positive samples associated with foodborne illness in Alberta, Canada (24). It has been indicated that the prevalence of MRSA varied dramatically around the world and reflects inappropriate antimicrobial administration and prevention practices (25, 26).
In this study, the mean $S$. aureus counts were $3.49,3.71,2.93,3.40$ and $3.23 \log _{10} \mathrm{cfu} / \mathrm{g}$ in the tested raw milk, Damietta cheese, Kareish cheese, ice cream and yoghurt, respectively, with an overall count of $3.41 \log _{10}$ $\mathrm{cfu} / \mathrm{g}$ (Table 2). The frequency of $S$. aureus counts in examined milk and dairy product samples is shown in table (3). It has been indicated that $75 \%(30 / 40)$ of raw milk samples exceeded the maximal limits of $100 \mathrm{cfu} / \mathrm{ml}$ set by both Egyptian standards (27) and European regulations (28), while $65 \%(26 / 40), 40 \%$ $(16 / 40), 40 \%(16 / 40)$ and $30 \%(12 / 40)$ of Damietta cheese, Kareish cheese, ice cream and of yoghurt samples, respectively (Table 2) exceeded the maximal limit of $100 \mathrm{cfu} / \mathrm{g}$ set for $S$. aureus by European Economic Communities food legislation for soft and fresh cheeses, frozen milk-based products and fermented dairy products (28). The Egyptian standards specified that soft cheeses (including Damietta and Kareish cheeses), ice cream and Yoghurt must be free from pathogenic organisms and their toxins. All cheese, ice cream, yoghurt samples in this study exceeded the permissible limits of $S$. aureus counts reported in Egyptian Standards. 
Table 2. Staphylococcus aureus counts $\left(\log _{10} \mathrm{cfu} / \mathrm{g}\right.$ or $\mathrm{ml}$ ) on Baird parker Agar (BP) from milk and dairy products

\begin{tabular}{lccccc}
\multicolumn{1}{c}{ Product } & $\begin{array}{c}\text { No. of samples } \\
\text { tested }\end{array}$ & Minimum & Maximum & Mean & $\begin{array}{c}\text { Samples exceeded the } \\
\text { maximal limit }\end{array}$ \\
\hline Raw milk & $4(0$ & 2.0 & 4.45 & $3.49^{*}$ & 3()$(75 \%)$ \\
Damietta cheese & 40 & 2.3 & 5.04 & $3.71^{*}$ & $26(65 \%)$ \\
Kareish cheese & 40 & 2.0 & 3.69 & $2.93^{*}$ & $16(40 \%)$ \\
Ice cream & 40 & 2.3 & 4.08 & $3.40^{*}$ & $16(40 \%)$ \\
yoghurt & 40 & 2.0 & 4.65 & $3.23^{*}$ & $12(30 \%)$ \\
All products & 200 & 2.0 & 5.04 & $3.41^{*}$ & $100(50 \%)$ \\
\hline${ }^{*}$ No significant difference at P $\leq 0.05$. & & & &
\end{tabular}

$\uparrow$ Maximum permissible limit is 2 log 10 efu/g or $\mathrm{ml}$ according to EEC (1992)

Table 3. Frequency of S. aureus count $\left(\log _{10} \mathrm{cfu} / \mathrm{m}\right.$ l or g) in examined milk and dairy products

\begin{tabular}{|c|c|c|c|c|c|}
\hline \multirow{2}{*}{$\begin{array}{c}\text { Intervals } \\
\left(\log _{10} \mathrm{cfu} / \mathrm{g}\right)\end{array}$} & Raw milk & Damietta cheese & Kareish cheese & Ice cream & Yoghurt \\
\hline & No $(\%)$ & $\mathrm{No}_{0}(\%)$ & No $(\%)$ & $N_{0}(\%)$ & $N_{0}(n)$ \\
\hline $0:<2$ & $10(25)$ & $14(35)$ & $24(60)$ & $24(60)$ & $28(7())$ \\
\hline $2:<3$ & $10(25)$ & $10(25)$ & $6(15)$ & $6(15)$ & $4(10)$ \\
\hline $3:<4$ & 10)(25) & $4(10)$ & $10(25)$ & $4(10)$ & $8(20)$ \\
\hline $4:<5$ & 10) $(25)$ & $10(25)$ & $0(0)$ & $6(15)$ & () ((1) \\
\hline $5:<6$ & () (()) & $2(5)$ & $0(0)$ & $0(0)$ & () ((1) \\
\hline Total & $40(100)$ & $40(100)$ & $40(100)$ & $40(100)$ & 4()$(10)(0)$ \\
\hline
\end{tabular}

Acidification is a way to reduce growth of hacteria in food processing. S. altreus is reported to be quite acid tolerant. In general, bacteria posses a multitude of defense mechanisms to cope with a sudden drop in $\mathrm{pH}$. Chan et al. (29) observed that $S$. aureus is killed at $\mathrm{pH}$ 2. Also, Pazakova et al. (30) proved that no $S$. aureus was detected in yoghurt produced from milk contaminated by $10)^{3}$ S. aureus cells after $48 \mathrm{~h}$ of cold storage. On the contrary, Zuniga Estrada et al. (31) reported that enterotoxigenic strains of $S$. cureus were able to survive the fermentation of milk with a yoghurt starter culture and they were inhibited after several days during storage of fermented products.

Acidity in both Kareish cheese and yoghurt has played a role in low incidence of $S$. auress in both types of dairy products. The high incidence of $S$. aureus species in Damietta cheese is indicative of poor hygienic measures during production, handling and distribution. On the other hand, the difference in the prevalence rates of $S$. altreus between the examined products may originate from the method of manufacture, storage and handling. Molecular characterization of MRSA isolates

We have isolated 414 MRSA strains from the milk and dairy product samples. One hundred and thirty four of these isolates were derived from raw milk, 88 from Damietta cheese, 26 from Kareish cheese, 138 from ice cream and 28 from yoghurt. All of the 414 isolates were tested by PCR for the presence of 4 different genes including 3 marker genes, namely nuc, coal and mecA in addition to one virulence genes (hla)

Detection of the marker genes; nuc, coa, and mecA in MRSA isolates

PCR analyses verified the existence of muc. $c o u$, and mecA genes at the expected molecular size of 660 bp (Fig. 2A). 10(0) bp (Fig. 2B), and 120() bp (Fig. 2C), respectively in all of the 414 isolates. Sequence analyses of the amplified genes were carried out, and the resultant sequences were subjected to the GenBank database for homology search using BLAST, Basic Local Alignment Search Tool. 
Detection of the virulence gene; hla in MRSA isolates

The hla gene which encodes the alphahemolysin (Hla) toxin is one of the main virulence factors of $S$. aureus and is formed by the most of $S$. aureus strains. Interestingly, all of the 414 MRSA isolated were positive for hla gene, which was detected at the expected molecular size of 744 bp (Fig. 3).

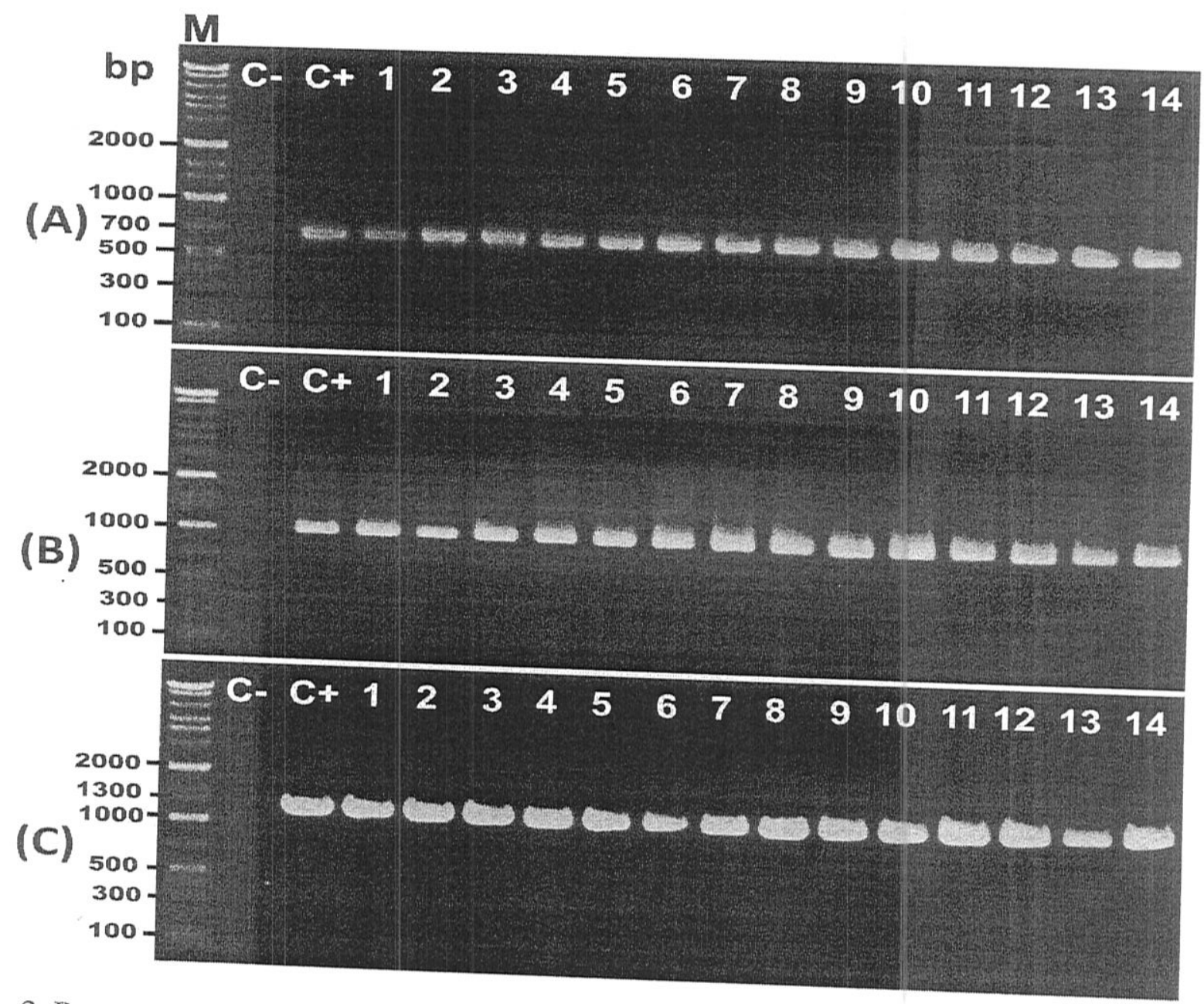

Fig. 2. Representative agarose gel electrophoresis for PCR products of the marker genes identified in the $S$. aureus strains $(\mathrm{n}=414)$ isolated from milk and different dairy products. Three microliters from the PCR products were separated by electrophoresis on $1.2 \%$ agarose gel. gene (B), and $1200 \mathrm{bp}$ for mect molecular size of $660 \mathrm{bp}$ for nuc gene (A), $1000 \mathrm{bp}$ for coa (Gene Ladder Wide 1) used as a refe (C), were visualized under UV light. M: DNA marker a negative control strain; positive strains for the target genes. 


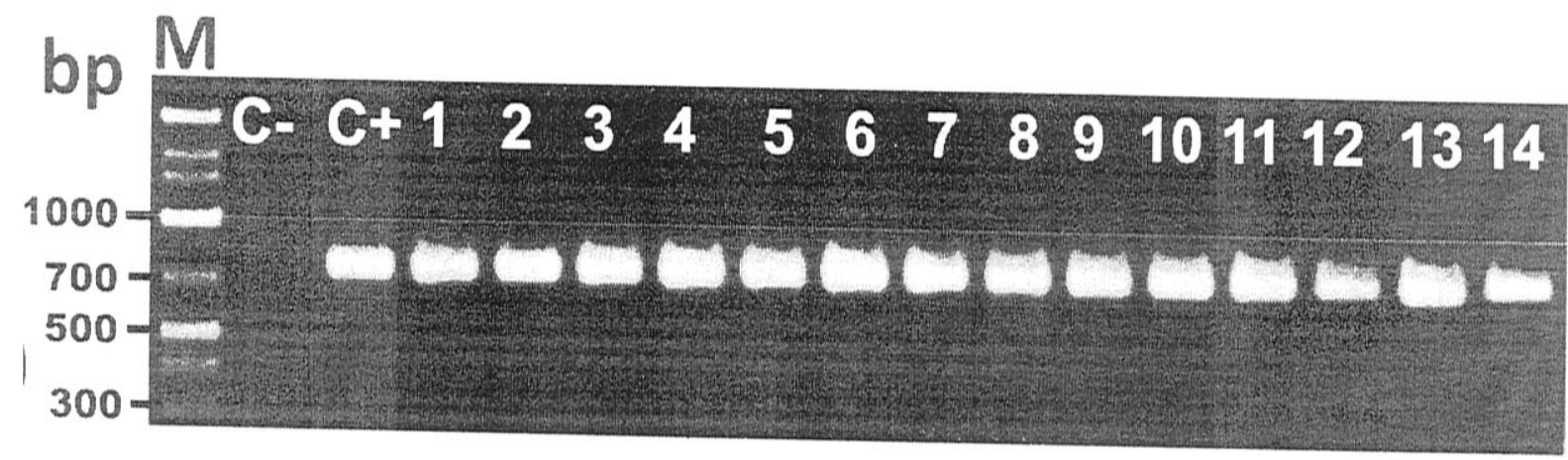

Fig.3. Representative agarose gel electrophoresis for PCR products of the virulence gene hla identilied in the $S$. aureus strains $(n=414)$ isolated from milk and different dairy products. Three microliters from the PCR products were separated by electrophoresis on $1.2 \%$ agarose gel. Amplified DNA ot the expected molecular size of 744 bp for hla gene was visualized under UV light. M: DNA marker (Gene Ladder Wide 1) used as a reference for fragment size; Lane C-: E. coli K12 DH5a as a negative control strain; Lanes from 1 to 14 are representative positive strains for the target genes.

Antimicrobial susceptibility of isolated MRSA strains

The antimicrobial drug susceptibility pattern for the 414 isolated MRSA strains is shown in lable (4). Of the 13 tested antimicrobials, the least effective drugs were penicillin G, cloxacillin, tetracycline, and amoxicillin with bacterial resistance pereentages of $87.9 \%, 75.9 \%, 65.2 \%$ and $55.6 \%$ respectively. Less effective drugs also included streptomycin, rifampicin, amikacin. chloramphenicol, which revealed bacterial resistance percentages of $44.9 \%, 36.7 \%, 35.3 \%$. and $30.9 \%$, respectively). The most effective antimicrobials against MRSA isolates wero vancomycin. sulphmethazole/trimethoprim. ciprofloxacin, netilmicin, and Gentamicin, which exhibited bacterial sensitivity percentages of $76.3 \%, 75.457() .1 \%, 69.1 \%$, and $63.3 \%$, respectively.

Table 4. Antimicrobial sensitivity pattern of MRSA isolated from milk and dairy products

\begin{tabular}{|c|c|c|c|}
\hline \multirow{2}{*}{ Type of Antimicrobials } & \multicolumn{3}{|c|}{ No. of MRSA isolates $(n=414)$} \\
\hline & $\mathrm{S}(\%)$ & $I(\%)$ & $\mathrm{R}(\%)$ \\
\hline Tetracycline $(30) \mu \mathrm{g})$ & $80(19.3)$ & $64(15.5)$ & 27()$(6.5 .2)$ \\
\hline Netilmicin $(30 \mu \mathrm{g})$ & $286(69.1)$ & $50(12.1)$ & $78(18.8)$ \\
\hline Amoxycillin $(10 \mu \mathrm{g})$ & $114(27.5)$ & $70(16.9)$ & $230(55.6)$ \\
\hline Cloxacillin $(5 \mu \mathrm{g})$ & $4(0.97)$ & $96(23.2)$ & $314(75.9)$ \\
\hline Streptomycin $(10 \mu \mathrm{g})$ & $134(32.4)$ & $94(22.7)$ & $186(44.9)$ \\
\hline Sulphamethazole/trimethoprim $(25 \mu \mathrm{g})$ & $312(75.4)$ & $44(10.6)$ & $58(14.0)$ \\
\hline Gentamicin $(10 \mu \mathrm{g})$ & $262(63.3)$ & $38(9.2)$ & $114(27.5)$ \\
\hline Penicillin G (10 IU) & $26(6.3)$ & $24(5.8)$ & $364(87.9)$ \\
\hline Rifampicin $(5 \mu \mathrm{g})$ & $222(53.6)$ & $40(9.7)$ & $152(36.7)$ \\
\hline Chloramphinicol $(30 \mu \mathrm{g})$ & $206(49.8)$ & $80(38.3)$ & $128(30.9)$ \\
\hline Ciprofloxacin $(5 \mu \mathrm{g})$ & $290(70.1)$ & $60(14.5)$ & $64(15.5)$ \\
\hline Amikacin $(30 \mu \mathrm{g})$ & $238(57.5)$ & $30(7.3)$ & $146(35.3)$ \\
\hline Vancomycin $(30 \mu \mathrm{g})$ & $316(76.3)$ & $62(15.0)$ & $36(8.7)$ \\
\hline
\end{tabular}




\section{Maha and Khalid}

Of the 414 MRSA strains tested, 348 $(84.1 \%)$ were multidrug resistance (resistant to 3 or more antimicrobials). The high frequency of multi-drug resistant MRSA isolated from milk and dairy products in this study spotted light and suggests needs to change sanitary regulation with regards to milk and most of dairy products consumed in Egypt. One idea is that multi-drug resistant bacteria, particularly Staphylococci associated with milk samples and its related products might be related to human contamination rather than contamination with animal origins (32). The antimicrobial susceptibility patterns observed for MRSA isolates may reflect the microbial adaptive response to the use and overuse of antimicrobials.

The present study concluded that milk and dairy products marketed in Mansoura, Egypt were highly contaminated with multidrug resistant MRSA, and such microbial contaminants harbor virulence gene, which have potential to cause severe infection in humans. This study presents the first genetic characterization of MRSA isolated from milk and dairy products in Egypt.

\section{REFERENCES}

1. Meyrand A, Boutrand-Loei S, RayGueniot S, Mazuy C, Gaspard C E, Jaubert $G$, Perrin $G$, Lapeyre $C$, and VernozyRozand C (1998): Growth and enterotoxin production of Staphylococcus aureus during the manufacture and ripening of Camembert-type cheeses from raw goats' milk. J Appl Microbiol., 85: 537-544.

2. Bennett $R W$ and Lancette $G A$ (eds.) (2001): Staphylococcus aureus. Chapter 12 pp. 222-228. In. BAM "Bacteriological Analytical Manual". US Food and Drug Administration, Centre for Food Safety \& Applied Nutrition.

3. Necidová L, Štústková Z, Pos pišilová $M$, Janš tová B, Strejček J, Dušková $M$ and
Karpišková $R$ (2009): Influence of soft cheese technology on the growth and enterotoxin production of Staphylococcus aureus. Czech J Food Sci., 27: 127-133.

4. Asao T, Kumeda Y, Kawai T, Shibata $T$, Oda H, Haruki K, Nakazawa $H$ and Kozaki, $S$ (2003): An extensive outbreak of Staphylococcus food poisoning due to the low-fat milk in Japan: estimation of enterotoxin $\mathrm{A}$ in the incriminated milk and powdered skim milk. Epidemiol Infect., 130: $33-4()$.

5. Jorgensen H, Mork T, Hogasen H and Rovik L (2005): Enterotoxigenic Staphylococcus aureus in bulk milk in Norway. J Appl Microbiol., 99: 158-166.

6. Heidinger J, Winter C and Cullor J (2009): Quantitative microbial risk assessment for Staphylococcus aureus and Staphylococcus enterotoxin $\mathrm{A}$ in raw milk. J Food Protect. 72: $1641-1653$.

7. Fusco V, Quero G, Morea M, Blaiotta $G$ and Visconti $A$ (2011): Rapid and reliable identification of Staphylococcus aureus harbouring the enterotoxin gene cluster (egc) and quantitative detection in raw milk by real time PCR. International Journal of Food Microbiology 144, 528-537.

8. Ertas $N$, Gonulalan Z, Yildirim Y and Kum E (2010): Detection of Staphylococcus aureus enterotoxins in sheep cheese and dairy desserts by multiplex PCR technique. Int J Food Microbiol., 142: 74-77.

9. Rosengren A, Fabricius A, Guss B, Sylvén $S$ and Lindqvist $R$ 2(010): Occurrence of foodborne pathogens and characterization of Staphylococcus altreus in cheese produced on farm-dairies. Int J Food Microbiol., 144:

10. Gücükoğlu A, Cadirci Ö, Terzi G, Kevenk $T$ and Alisarli $M$ (2013): Determination of Enterotoxigenic and Methicillin Resistant Staphylococcus aureus in ice cream. J Food Sci., 78: M738- 741.

11. Zakary $E$, Nassif $M$ and Mohammed $G$ (2011): Detection of Staphvlococcus cureus in bovine milk and its product by real time 
PCR assay. Global J Biotechnol Biochem., 6: 171-177.

12. Le Loir Y, Baron F and Gautier M (2003): Staphylococcus areus and food poisoning. Genet Mol Res., 2: 63-76.

13.ICMSF "International Commission on Microbiological Specifications for Foods" (1996): Staphylococcus aureus. Microorganisms in Food 5: Characteristics of Microbial Pathogens. In. Roberts, T. A., Baird-Parker A. C., Tompkin, R. B. (Eds.), Blackie Academic and Professional, London, pp. 299-333.

14.Pereira V, Lopes C, Castro A, Silva J, Gibbs $P$ and Teixeira $P$ (2009): Characterization for enterotoxin production, virulence factors, and antibiotic susceptibility of Staphylococcus aureus isolates from various foods in Portugal. Food Microbiol., 26: 278-282.

15. Mead P S, Slutsker L, Dietz V, McCaig L $F$, Bresse $J S$, Shapiro $C$, Griffin $P M$ and Tauxe R V (1999): Food-related illness and deaths in the United States. Emerg Infect Diseases., 5: 6017-625.

16. Kluytmans J, Van Leeuwen W, Goessens $W$, Hollis $R$, Messer $S$, Herwaldt $L$, Bruining $H$, Heck $M$, Rost $J$ and van Leeuwen $N$ (1995): Food-initiated outbreak of methicillin-resistant Staphulococcus aureus analysed by pheno and geno-typing. J Clinic Microbiol., 33: 1121-1128.

17. Arsic B, Zhu $Y$, Heinrichs $D E$ and McGavin M $J$ (2012): Induction of the staphylococcal proteolytic cascade by antimicrobial fatty acids in community acquired methicillin resistant Staphylococcus atreus. PLOS ONE 7(9): e45952.

\section{Sallam K I, Abd-Elghany S M and Tamura}

$T$ (2014): Prevalence, molecular characterization and antimicrobial resistance profile of methicillin-resistant Staphylococcus aureus (MRSA) in retail chicken products. Syst Appl Microbiol., (in Press).
19. Matyi S, Dupre J, Johnson W, Hoyt P, White D, Brody $T$, Odenwald $W$ and Gustafson $J$ (2013): Isolation and characterization of Staphylocoocus aureus strains from a Paso del Norte dairy. J Dairy Sci., 96: 3535-3542.

20. Normanno G, La Salandra G, Dambrosio A, Quaglia $N$, Corrente $M$, Parisi $A$, Santagada G, Firinu A, Crisetti $E$ and Celano $G$ (2007): Occurrence, characterization and antimicrobial resistance of enterotoxigenic Staphylococcus aureus isolated from meat and dairy products. Int J Food Microbiol., 115: 290-294.

21.Lee J H (2003): Methicillin (Oxacillin)resistant Staphylococcus aureus strains isolated from major food animals and their potential transmission to humans. Appl Environ Microbiol., 69: 6489-6494.

22. Mirzaei $H$, Tofighi A, Sarabi $H K$ and Farajli, $M$ (2011): Prevalence of Methicillin- resistant Staphylococcus aureus in raw milk and dairy products in Sarab by culture and PCR techniques. J Anim Vet Adv., 10: 3107-3111.

23. Kav K, Col $R$ and Ardic $M$ (2011): Characterization of Staphylococcus aureus isolates from white-brined Urfa cheese. J Food Protect., 74: 1788-1796.

24. Crago B, Ferrato C, Drews $S J$, Sevenson $L W$, Tyrrel $G$ and Louie $M$ (2012): Prevalence of Staphylococus aureus and methicillin-resistant $S$. aureus (MRSA) in food samples associated with foodborne illness in Alberta, Canada from 2007 to 2010. Food Microbiol., 32: 202-205.

25. Sader $H S$, Streit J M, Fritsche $T R$ and Jones $R \quad N$ (2006): Antimicrobial susceptibility of gram-positive bacteria isolated from European medical centres: results of the Daptomycin Surveillance Programme (2002-2004). Clin Microbiol Infect., 12: 844-852.

26. Chen $C B$, Chang $H C$ and Huang $Y C$ (2010): Nasal meticillin-resistant Staphylococcus aureus carriage among intensive care unit hospitalised adult patients in a Taiwanese medical centre: one 


\section{Maha and Khalid}

time-point prevalence, molecular characteristics and risk factors for carriage. $J$ Hosp Infect., 74: 238-244.

27.ES "Egyptian Standards" (2005): Milk and Dairy products, part 1: Raw milk, Egyptian organization for standardization and quality control, Directive No.154-1, Arab Republic of Egypt.

28. EEC "European Economic Community" (1992): Council Directive No 92/46/EEC, 1992. Laying down the health rules for the production and placing on the market of raw milk, heat treated milk and milk based products. OJEC., No. L.268, 1-32.

29. Chan $P$, Foster $S$, Ingham $E$, and Clements M (1998): The Staphylococcus aureus alternative sigma factor $\varsigma^{B}$ controls the environmental stress response but not starvation survival or pathogenicity in a mouse abscess model. J Bacteriol., 180: 6082-6089.

30. Pazakova J, Turek $P$, and Laciakova A (1997): The survival of Staphylocoocus aureus during the fermentation and storage of yoghurt. J Appl Microbiol., 82: 659-662.

31. Zúnigiga Estrada A, Sánchez Mendoz, Mota de la Garza $L$ and Ortigoza Ferado $J$ (1999): Behavior of enterotoxigenic strains of Staphylococcus aureus in milk fermented with a yogurt starter culture. Rev Latinoam Microbiol., 41: 5-10.

32. Spanu V, Spanu C, Virids S, Cossu F, Scarano $C$ and De Santis E (2012): Virulence factors and genetic variability of Staphylococcus aureus strains isolated from raw sheep's milk cheese. Int J Food Microbiol., 34: 587-590.

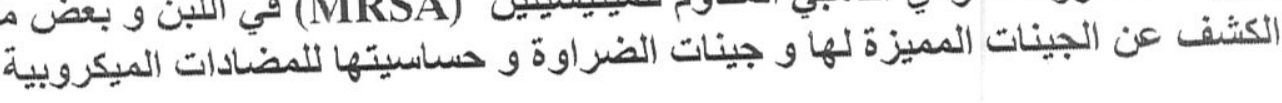

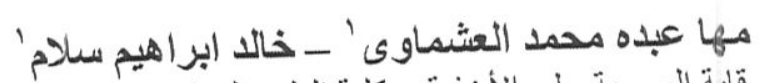

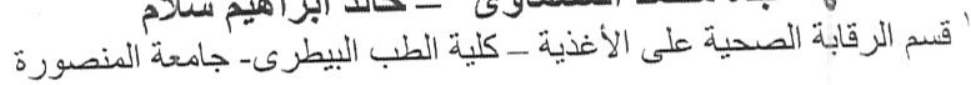

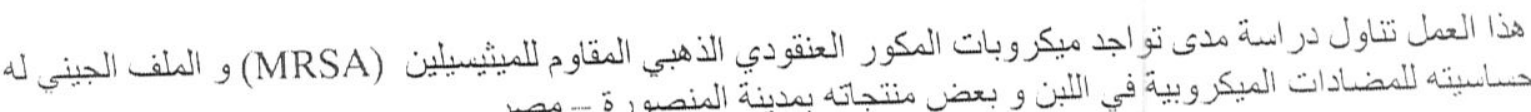

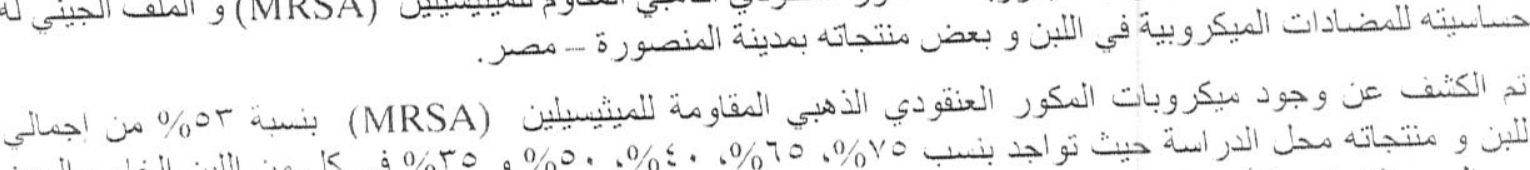

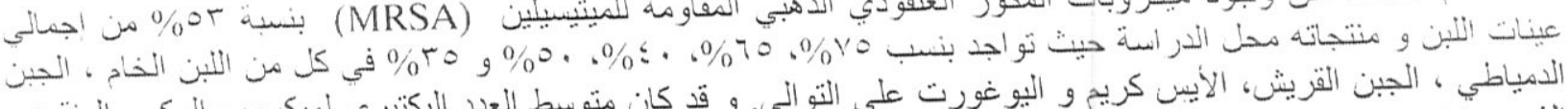

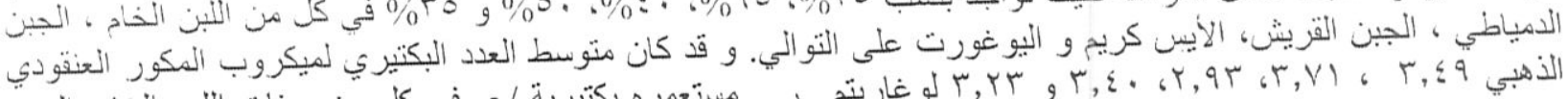

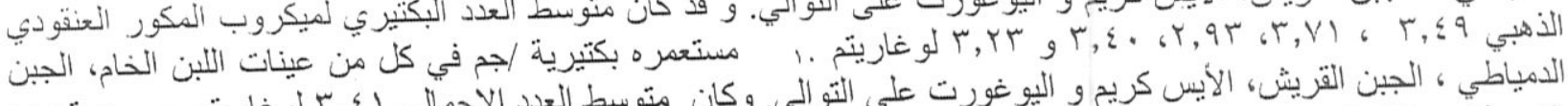

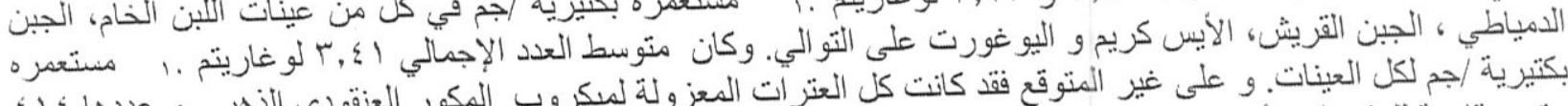

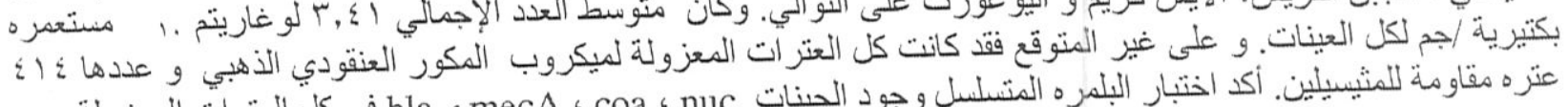

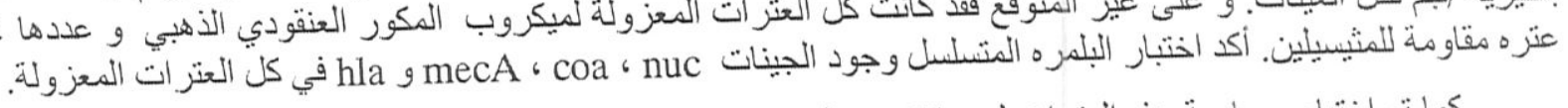

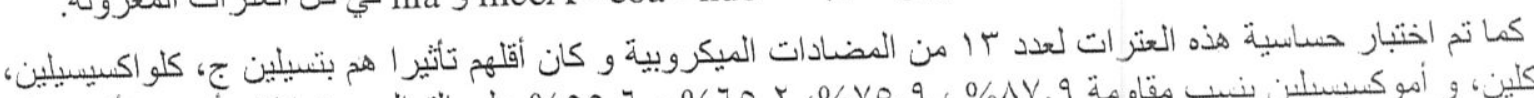

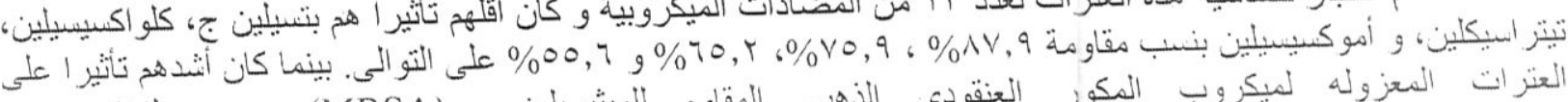

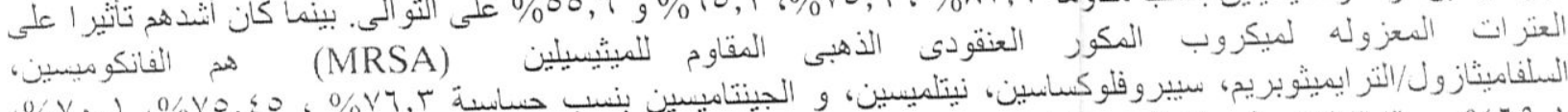

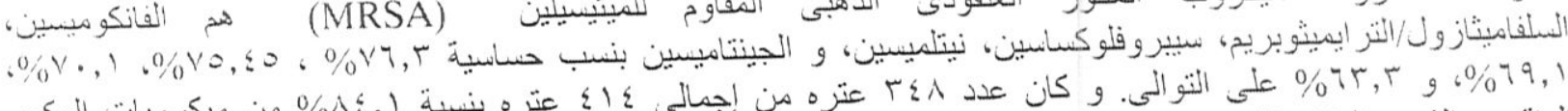

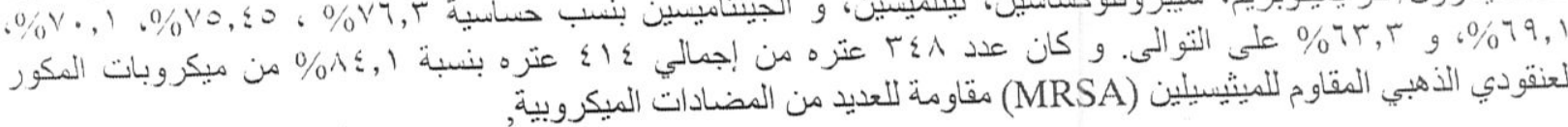

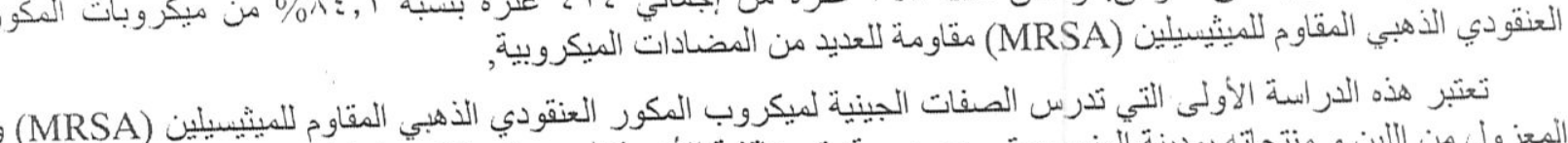

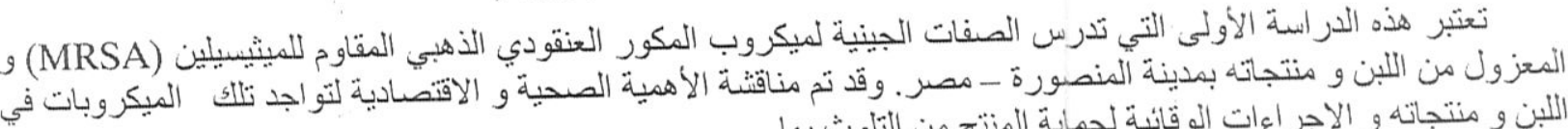

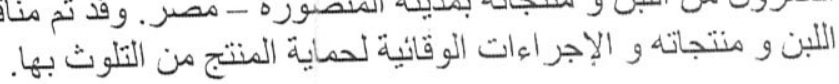

